\title{
Research support services to small and medium enterprises by university libraries in Uganda: An entrepreneurial and innovation strategy
}

\begin{tabular}{|c|c|}
\hline \multicolumn{2}{|c|}{$\begin{array}{l}\text { Authors: } \\
\text { Robert S. Buwule }{ }^{1,2} \\
\text { Stephen M. Mutula }\end{array}$} \\
\hline \multicolumn{2}{|c|}{$\begin{array}{l}\text { Affiliations: } \\
{ }^{1} \text { Faculty of Special Needs and } \\
\text { Rehabilitation, Kyambogo } \\
\text { University Library, Uganda }\end{array}$} \\
\hline \multicolumn{2}{|c|}{$\begin{array}{l}{ }^{2} \text { School of Social Sciences, } \\
\text { University of KwaZulu-Natal, } \\
\text { South Africa }\end{array}$} \\
\hline \multicolumn{2}{|c|}{$\begin{array}{l}{ }^{3} \text { College of Humanities, } \\
\text { University of KwaZulu-Natal, } \\
\text { South Africa }\end{array}$} \\
\hline \multicolumn{2}{|c|}{$\begin{array}{l}\text { Corresponding author: } \\
\text { Robert Buwule, } \\
\text { burosta@gmail.com }\end{array}$} \\
\hline \multicolumn{2}{|c|}{$\begin{array}{l}\text { Dates: } \\
\text { Received: } 05 \text { Aug. } 2016 \\
\text { Accepted: } 03 \text { July } 2017 \\
\text { Published: } 31 \text { Oct. } 2017\end{array}$} \\
\hline \multicolumn{2}{|c|}{$\begin{array}{l}\text { How to cite this article: } \\
\text { Buwule, R.S. \& Mutula, S.M., } \\
\text { 2017, 'Research support } \\
\text { services to small and medium } \\
\text { enterprises by university } \\
\text { libraries in Uganda: An } \\
\text { entrepreneurial and } \\
\text { innovation strategy', South } \\
\text { African Journal of } \\
\text { Information Management } \\
\text { 19(1), a780. https://doi.org/ } \\
\text { 10.4102/sajim.v19i1.780 }\end{array}$} \\
\hline \multicolumn{2}{|c|}{$\begin{array}{l}\text { Copyright: } \\
\text { (c) 2017. The Authors. } \\
\text { Licensee: AOSIS. This } \\
\text { is licensed under the } \\
\text { Creative Commons } \\
\text { Attribution License. }\end{array}$} \\
\hline \multicolumn{2}{|l|}{ Read online: } \\
\hline 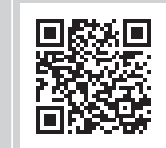 & $\begin{array}{l}\text { Scan this QR } \\
\text { code with your } \\
\text { smart phone or } \\
\text { mobile device } \\
\text { to read online. }\end{array}$ \\
\hline
\end{tabular}

Background: Sub-Saharan Africa tops the list of poorest regions in the world. The region is characterised by poverty, high unemployment rates, hunger and disease. Small and medium enterprises (SMEs) the world over contribute significantly towards social economic growth and have the potential if well harnessed to contribute towards the achievement of Sustainable Development Goals (SDGs) and also reverse the cycle of poverty on the African continent. Most university libraries in the developed world have put in place strategies to re-engineer information on research and innovation (R\&I) for SMEs to support entrepreneurship and innovation programmes. However, university libraries in Africa are still lagging behind in this regard despite the fact that the region has the highest number of SMEs.

Objectives: The objectives of this study were to: investigate how university libraries in Uganda are managing the universities' research output; find out how the research output is disseminated to SMEs for their entrepreneurial activities, to understand how SMEs access and use R\&I information for their entrepreneurial programmes; and propose feasible strategies of how best university libraries can re-engineer the dissemination of the research output for use by SMEs in their entrepreneurial endeavours.

Method: The study used document analysis which is a qualitative data collection method. Empirical literature related to the research variables of the study was reviewed through systematic searching of manual and electronic documents on how university libraries treat their R\&I information in relation to entrepreneurship.

Results: The findings demonstrate that university libraries can re-engineer their R\&I information services for SMEs through: repackaging R\&I information in formats and languages easily accessible by SMEs; creating informal social networks for information sharing among SMEs; creation of R\&I information library corners; University Library Consortia advocating for this concept; periodical announcements of new R\&I information in the library through emails to SMEs; organising SME days in the library; creation of SME pages on the library website; conducting information literacy training sessions for SME entrepreneurs; and adding this concept in the library and information science curricular.

Conclusion: This article discusses how university libraries, from a developing country context such as Uganda, can re-engineer research output for SMEs and use it to develop innovative solutions that can contribute positively towards SDGs and the social economic transformation of Africa at large.

\section{Introduction}

Sub-Saharan Africa tops the list of the poorest regions in the world. According to Valentina (2016), countries that include but are not limited to Democratic Republic of Congo, Central African Republic, Burundi, Malawi, Liberia, Niger, Guinea, Madagascar and Guinea-Bissau are among the poorest countries in the world. These countries are characterised by poverty, high unemployment rates, hunger and disease. Consequently, governments in these countries are encouraging the establishment and sustenance of small and medium enterprises (SMEs) (Sekanjako 2016) to drive the economy. SMEs worldwide contribute significantly towards social economic growth and gross domestic product (GDP) in most countries (Beck, Demirguc-Kunt \& Levine 2005).

Some university libraries in the developed world are making attempts to develop strategies of disseminating information on research and innovation (R\&I) to support entrepreneurship and 
innovation programmes in small business enterprises (Johnson et al. 2015). However, university libraries in Africa are lagging behind in this regard (Chiware 2010).

\section{Objectives of the study}

The aim of this study were to:

- investigate how university libraries are managing the universities' research output;

- find out whether the research output is disseminated to SMEs;

- understand how SMEs access and use R\&I information for their entrepreneurial programmes;

- propose feasible strategies of how best university libraries can re-engineer the dissemination of the research output for use by SMEs in their entrepreneurial endeavours.

\section{The global perspective of university libraries}

Traditionally, there are four types of libraries: academic, public, school and special libraries (Burkland 1999). However, when users like small-scale entrepreneurs are interested in information that emphasises high specificity on R\&I, they are likely to find it in academic and special libraries (Burkland 1999). University libraries fall under academic libraries and they collect, store and disseminate R\&I information among other duties (Johnson et al. 2015).

Scores of users visit university libraries to meet their information needs (The Conversation 2016). Consequently, spaces in these libraries are increasingly being converted from storing shelves of print books to user-friendly spaces for group study, discussions, collaborative learning, invention and innovation (Barclay 2015). For example, at the Grand Valley State University Library in California in the United States of America, people from the market place come for assistance on data analysis, writing research reports, graphic designing and public speaking. The library offers specialised spaces for preparing, digital and media collaboration, as well as practices for presenters (Grand Valley State University 2016).

Similarly, the North Carolina State University Library (2016) in North America and the University of Pretoria (2015) in South Africa offer maker spaces where library users practically handle and use modern electronic gadgets that scan, cut and mill. They also have $3 \mathrm{D}$ printers which they use to connect to the Internet and create innovative objects. Library users do not stop there. They further patronise the production media studios and laboratories for digital media for visualisation and practicing music. All these specialised library spaces are used to test research outcomes so as to get fresh innovations from them (Johnson et al. 2015). Such practices have encouraged a lot of innovations to take place in the developed countries.

Freeman (2005) asserts that the advancement of university libraries has reached a level where they are encouraging their patrons to use the library services to actively participate in a life of continuous learning. With the coming of technology, many thought that the virtual library would replace the physical library. Although this has not yet happened as forecasted, nonetheless technology has had an unprecedented and an astonishing influence on university libraries. Today, these libraries are expected to use technology to serve a significant social role in the community. Moreover, academic libraries are increasingly becoming a place where people from all walks of life and persuasion come together to experience the richness of scholarship. University library users also, in turn, want to experience a sense of inspiration and enjoy the library as a contemplative oasis (Freeman 2005).

The Libraries Transform (2015a) in conjunction with the American Library Association officially launched a public nationwide awareness drive highlighting the peculiar role libraries can play to transform society in this modern digital era. They emphasise the fact that the attention of the drive is not on what libraries have for the library patrons but what libraries can do for and with their patrons. Good enough the drive embraces all types of libraries ranging from academic, public and special libraries. This, therefore, means that the university library is not the only one that needs to be reengineered but all kinds of libraries. Essentially, the goal of this campaign is to change the perception of libraries from being quiet places of finding books and reading, to spaces of shared understanding and dynamic centres for learning in the digital age (Libraries Transform 2015b). Incidentally, this perception of libraries being places for storing books and quiet study is still very dominant in sub-Saharan Africa.

Generally from an international perspective, university libraries are equipping and maintaining their libraries with the necessary tools and commercially compliant systems to aid the dissemination of R\&I information to their researchers and entrepreneurs (Miles et al. 1995). In some universities like Michigan State University, they have gone ahead to create a post of an entrepreneurship librarian and his or her duties rotate around engaging business people and the community with their innovative and entrepreneurial programmes (Sarin 2013). It is interesting to note that this approach has acted as a stimulus for their cutting-edge entrepreneur and innovative programmes for their business enterprises (Peterson 2005). It is worth mentioning here that though this campaign is very vibrant in the United States and is yielding fruit, it is still picking up in other parts of the world.

\section{African university libraries context}

The International Federation of Library and Information Associations (2015) at its annual conference in Cape Town, South Africa, called on its membership to provide the necessary resources for the development of African libraries to become powerful knowledge partners of governments in development. African governments are now called upon to include libraries on their agenda for the attainment of the Sustainable Development Goals (SDGs) (International 
Federation of Library and Information Associations \& Institutions 2016). Some of these efforts could be directed towards supporting SMEs because this region has the highest number of SMEs in the world (Fjose, Grünfeld \& Green 2010).

One major factor that sets apart the developed world from their developing counterparts is the way the former manages R\&I information through their universities (Chiware 2010). R\&I information found in university libraries that may be of interest to SMEs includes industry, technology, consultancy on developing business ideas, plans, aiding entrepreneurs, networking, identifying funding opportunities, resources mobilisation, sources of business financing, market research, information on competitors, customer care, benchmarking, patents and trademarks among others (Drew 2007:3-4; Schauder 1987:36). Because this practice is being employed by developed countries and it is clearly assisting in boosting business enterprises, there is no reason why it cannot be practiced by libraries and SMEs in developing countries. African university libraries can now borrow a leaf from their counterparts in the developed world and facilitate the use of this information by SMEs so as to cultivate more entrepreneurial ideas (Ikoja-Odongo 2002). The research generated in the universities both in developed and developing countries is essential in solving problems of all sectors of the national economy including, among others, health, agriculture, education, transport, infrastructure and social services.

In sub-Saharan Africa, technology is slowly being embraced and university libraries are digitising books, issuing library resources in electronic formats (Tambwe 2016) but not much is being done to re-engineer the library to be a social place for researchers and innovators. Many university libraries in subSaharan Africa are still focusing on the collections, buildings, and other infrastructure and using them to serve students and staff of the institution. Although it is true that the university libraries' principal mandate is to promote and enrich the students' and staff's educational experience of learning and teaching, respectively, there is still more they could do especially with regard to servicing SMEs. In recent years, there is an awakening to the fact that libraries are fundamentally about people (Freeman 2005).

Some scholars like Neal and Mcclure (2003) have questioned whether university libraries can beat the academic bureaucracy and effectively re-engineer their structures and strategies to embrace corporate attitude and environment. Many of them are already struggling with budget cuts, strained staffing and other challenges (Chiware 2010; Johnson et al. 2015). Indeed re-engineering starts from reviewing the institutional mission and goals, to centralised planning and resource allocation to cater for the establishment and staffing of functional library R\&I systems and units.

The re-engineering of information in university libraries to serve SMEs has far-reaching financial and organisational implications such as investing in costly technologies like innovation testing laboratories, 3D printing services, invention stores, web support services and electronic publishing (Neal \& Mcclure 2003). Nevertheless, libraries can start small with simple and less costly R\&I services like setting up R\&I consultancy, repackaging R\&I information and selective dissemination of R\&I information to SMEs, among others. As the users appreciate the service, it can then be stepped up with the support of the university administration. There must be adequate funding made available to university libraries so that they can produce adequate and efficient R\&I information services (Ajidahun 2006) to service the needs of SMEs.

Owing to the fact that there is a lot of research generated in institutions of higher learning (Johnson et al. 2015), university libraries are expected to lay strategies for permanent access to R\&I information and other digital scholarly resources. The electronic environment we live in today is very dynamic and complex. Information is constantly changing and without a clear laid-out strategy, an academic library risks losing a lot of vital information which supports its research services. Kanyengo (2006) advises that at the moment it is imperative that university libraries offer technical leadership in searching for solutions that guarantee the conservation, preservation and perpetual access to the continent's R\&I information. This technical assistance should be regulated by a proper policy framework encompassing technological, scientific, documentation and archival skills.

\section{University libraries in a Ugandan context}

According to the Uganda universities and other Tertiary Institutions' Act 2001, for an institution to be recognised as a university, it has to have a university library and this facility should be physical, accessible and well furnished (Republic of Uganda 2006). Currently, Uganda has 46 universities of which 7 are public and 39 are private (Uganda National Council of Higher Education 2016).

Currently, a lot of research output on R\&I that relates to entrepreneurship is generated in universities (Chiware 2010) and other institutions of higher learning in Uganda but not much of this research cascades to the users in the informal sector where most SMEs fall (FSD Africa et al. 2015). As already pointed out, the university libraries of the developed world are re-engineering their R\&I to serve SMEs, and the same should be encouraged in the Ugandan university libraries so that entrepreneurs from SMEs can access and use the R\&I information to generate innovative programmes for their businesses. Tibenderana et al. (2010) asserts that university library users in Uganda tend to patronise library services mainly because of the relevancy of the library service, its social demands, the benefits expected from it and the conditions facilitating its availability. Therefore, Ugandan university libraries are trying to ensure that the library resources available for students and staff are patronised maximally along these modes.

Kinengyere (2007) further asserts that university libraries carry out periodical training sessions where they equip their 
users with different skills of understanding the kind of information needs they have, accessing the available library information resources and evaluating the authenticity of information obtained. This can be built upon to ensure services to SMEs are developed and delivered in more effective ways.

\section{Research methodology}

This study used a document analysis method of data collection. Document analysis is a qualitative data collection research method that focuses on reviewing empirical literature related to the research variables of the study (Bowen 2009). An explicit criterion was used to select and review available literature as suggested by Fink (1998:16), and the literature searching strategy broadly followed these stages:

- The researchers identified key words based on the topic of study. The keywords included subject headings and author names of experts of the concept under study.

- The researchers then selected the computerised databases, institutional repositories and bibliographies from the Internet, from which they carried out the literature searches.

- They ran the searches and only selected high-quality studies with empirical methodologies, feasible and realistic research findings.

- They finally conducted manual searches from unpublished relevant literature in form of reports, newspaper articles and monographs on the universities' research output and how university libraries are using it to support entrepreneurship.

This method efficiently generated a large number of scholarly articles published in a wide variety of journals (Zou \& Stan 1998). Because universities libraries predominantly serve the students and academic staff, this approach revealed how university libraries treat their R\&I information in relation to meeting the entrepreneurship information needs of their surrounding user communities.

\section{Research findings}

Below is the research support in the form of entrepreneurial and innovation strategies which university libraries can employ to support SMEs from the reviewed literature.

\section{Research and innovation information sources}

In the ideal business world, for an enterprise to have a sound entrepreneurial programme driven by cutting-edge innovations, it has to have a solid research and development (R\&D) unit that carries out scientific investigations on the issues affecting the general running of business. This R\&D unit is expected to come up with timely solutions for the betterment of the business (Van De Vrande et al. 2009). This model is called closed innovation and is used by big enterprises to outdo SMEs. However, owing to labour mobility, widespread and dispersed knowledge in the business world, firms can no longer innovate in isolation.
They need to engage with different partners to acquire fresh ideas and resources in order to stay abreast of competition (Dahlander \& Gann 2010).

Increasingly, established business enterprises are relying more on external sources for R\&I information instead of their internal R\&D sources (Chesbrough 2006). They take advantage of creating collaborative relationships between universities and enterprises. According to Perkmann and Walsh (2007), university-industry relationships are widely practised and they have created platforms for open innovation, collaborative research, university-industry research centre, technology transfer, academic consultancy and analysis. If only the university library can be added in this equation, then the library could strengthen and create more of such relationships where many business enterprises would get access to well-processed and customised R\&I information.

Brush (1992) concurs with above because from a survey he carried out on entrepreneurs working in manufacturing industries, nearly $100 \%$ were relying on external sources for their R\&I information. They would access it from trade magazines, competitors' sales brochures, advertisements, newspapers, general magazines and informal networks. So this is an indication that SMEs do not have capacity to set up their own R\&D units (Lee et al. 2010) that generate R\&Is to inform their entrepreneur decisions. According to Aikaeli (2007), SMEs' inability to get R\&I information cripples their capacity to innovate and they resort to copying other peoples' innovations and investments. To avoid this kind of inbreeding, university libraries can, therefore, be their fallback position and supply them with R\&I information. The importance of this is that several university libraries around the world are embracing the open-access movement (Johnson et al. 2015). They are slowly embracing this concept of eliminating any form of financial and intellectual barriers that impedes the dissemination of scholarly works which includes R\&I information.

\section{Small and medium enterprises and their access to information on research and innovation}

SMEs have differing definitions in different countries around the world. According to Jeffcoate (2005), in Australia, an SME is a company that employs 250 people or less, while in China an SME is a firm which employs 2000 people or fewer and has an annual turnover of RMB Yuan 300 million (\$ 43478260 ) and total assets worth RMB Yuan 400 million (\$57 971014 ) or less (Zeng, Xie \& Tam 2010). In South Africa, an enterprise is categorised as small if it has $21-50$ workers, while a medium enterprise is one that has 51-200 workers (The Republic of South Africa 1996, 2003). In Tanzania, SMEs are those enterprises with 1-100 workers and have investment in capital worth 800 million Tanzanian Shillings (\$ 357 941) (Aikaeli 2007).

In Uganda, the Ministry of Finance, Planning and Economic Development (2011) defines a small enterprise as one with 
5-50 workers, with total assets and an annual revenue worth 360 million Uganda Shillings (\$102 857), and for an enterprise to be considered 'medium', it has to employ more than 50 workers with total assets and an annual revenue of between Uganda Shillings 360 million to 30 billion (\$102 8578571 428). The Uganda Bureau of Statistics carried out a Census of Business Establishments in Uganda and it was reported that there are 458106 business establishments broken down in four categories: (1) micro, (2) small, (3) medium and (4) large enterprises, where micro were $70 \%$; small, 20\%; medium, 10\%; and large, 0\% (Uganda Bureau of Statistics 2011:34). Premised from this statistic, the business establishments that fall under SMEs are 137431 (30\%) (Uganda Bureau of Statistics 2011).

SMEs around the world contribute a high percentage to the nation's GDP. For example, in Singapore, SMEs employ over $50 \%$ of their population (Hin \& Subramaniam 2005). According to Machacha (2002), in the global economy, SMEs are a stimulus for economic growth and development mainly through the use of innovations to create employment opportunities (Al-Qirim 2005). SMEs, therefore, have the potential if well harnessed to contribute towards the achievement of SDGs.

In sub-Saharan Africa, there are few jobs created in the formal sector so most people find jobs in the informal sector where SMEs account for most of the new employment opportunities created (Mutula 2005). For example, in Uganda, the Ministry of Finance, Planning and Economic Development (2011) states that SMEs collectively constitute about $90 \%$ of private sector production, employing more than 2.5 million people and operate largely in the informal sector. This is further confirmed by Nakibuule (2015) who posits that SMEs are increasingly playing a role of sustaining the economy where they contribute up to $75 \%$ of the GDP through using innovations to create jobs.

The 2014 Global Entrepreneurship Monitoring report rated Uganda in the world as one of the most entrepreneurial countries, where $28 \%$ of Uganda's adult population are entrepreneurs or have engaged in some form of entrepreneurial activities (Kulabako \& Ojambo 2016). However, despite the fact that it has a good statistic of starting business ventures, this report further states that half of all these enterprises collapse before seeing their second birthday. The report rates the failure rate of SMEs in Uganda up to $60 \%$. Financial Sector Deepening (FSD) Africa et al. (2015) also agree with the above because from their survey they noted that SMEs in Uganda are relatively young enterprises, where $69 \%$ of them have not existed for more than 10 years. They further state that most SMEs owners started them up using their own funds, and nearly three quarters operate as sole proprietorships. These owners are also relatively educated with secondary education or higher.

With such a moderate education level, it is surprising that SMEs do not have any assured access to technical business information or libraries services (Aikaeli 2007; Mutula 2005).
This, therefore, explains why for them to survive they need regular technical assistance (FSD Africa et al. 2015). This is where university libraries can play an important role in offering assistance to address the issues that threaten their survival (Ponelis 2011).

Sharing and collaboration are more dependent on people than technology (Sridhar 2007). Though SMEs are adopting information communication technologies (ICTs) and greatly facilitating information sharing and collaborative working, information sharing remains a complex human process which is subject to psychology of individuals and their professional and cultural predisposition. Sridhar (2007) continues to assert that one important barrier in sharing corporate information is lack of common information retrieval tools. ICTs ease information retrieval but they are unable to evaluate retrieved information. Sridhar (2007) further notes that ICTs still need human intervention when managing personalised and community information retrieval systems. So university libraries should work with the ICTs to provide quality, timely, relevant, dependable R\&I information to SMEs for the betterment of their entrepreneurial and innovative programmes (Johnson et al. 2015).

For SMEs to enjoy a competitive advantage, they need to integrate the business strategy with the information management function such that the creation, use, dissemination, and storage of information is enhanced (Mutula \& Van Brakel 2007). The government on the contrary is expected to effectively procure technical and human resources to boast SMEs' technological, research and development capacity needs. Similarly, because governments are putting up interventions to support SMEs, they can bring university libraries on board as partners in serving SMEs with R\&I information (Lee et al. 2010).

It should be noted here that SMEs are vulnerable because they predominantly operate in an informal and local environments (Hin \& Subramaniam 2005). So if university libraries are to effectively serve them with R\&I information, they need to customise these services in a user-friendly way. University libraries need to tailor the R\&I information services in a way that can appeal to SMEs' vulnerability. This would, therefore, call for repackaging information in formats that are easily accessible by SMEs.

\section{Re-engineering university libraries to support small and medium enterprises research and innovation information needs}

Since half a decade ago, the Uganda Industrial Research Institute (UIRI) has been working on a project of making toothpicks out of bamboo, however, though this project was successful, the product has not yet been translated into commercial production. This can be evidenced by young men vending toothpicks imported from Kenya (Sseppuuya 2016). Generally, Uganda's economy is characterised by low productivity and highly import driven which is leading to high unemployment and an unstable currency. Instead of 
business men investing in such innovative ideas like making toothpicks out of bamboo and creating better employment of these young men who vend them but also save the country's forex, they are more interested in investing in real estate which does not create employment opportunities or generate forex. It is not only tooth picks but also tissue, napkins, serviette and many other simple technology products that can be manufactured by SMEs or small-scale industries. The reality on the ground is that you find most of these imported from China, United Arab Emirates and other countries abroad.

From Sseppuuya's observation, it is clear that the innovations are there in universities and research institutions but there is a lacuna of a system picking this information on R\&I, repackaging it in a form that SME businessmen can access and use for their entrepreneur programmes and investments. The repackaging of R\&I may take several forms such as:

- simplifying the language of R\&I information from the academic and scholarly to a simple language understandable by a layman;

- translating the information from the English language to local indigenous languages;

- repackaging it from print or text into audio or video to address the prevalent poor reading culture;

- transcribing it into braille, sign language for persons with disabilities.

Like Mansell (2010) argues, this re-engineering should critically focus on the issues of ICT and accessibility, illiteracies of users that may hinder this kind of adoption, the university libraries' accountability to the researchers and SME entrepreneurs, affordability, staffing of knowledgeable library staff members and perception levels of the beneficiaries (SMEs)

\section{Suggestions for re-engineering university libraries for small and medium enterprises}

According to Rodrigues (2001), library users with polished skills in conducting library information searches generally get more comprehensive information compared with users without such research skills. Going by this approach, universities in Uganda have to make efforts to develop the information gathering and management skills of their users most especially those who consume R\&I information. This probably will make them more thorough when they are searching for R\&I information for their entrepreneurial and innovative business programmes.

University libraries can further take advantage of the importance of social networks. Drew (2007) asserts that strong results do not only come from what you know only, but also from who you know as well. Librarians in university libraries have an opportunity of creating informal networks of SMEs who share the same trade which can spur collaborative entrepreneurial and innovative activities among SMEs of the same trade. They can offer $1 \mathrm{~h}$ a week or month of brainstorming on a topical issue like business planning, financing of business proposals, resources mobilisation to mention but a few. Such sessions can also act as mentorship opportunities between the senior entrepreneurs and the junior ones.

It is understandable that changes, university libraries in the western world are making in re-engineering their services for SMEs, require heavy investments nevertheless there are other low-budget simple innovative ideas university libraries in sub-Saharan Africa can employ to boost SMEs entrepreneurial and innovative programmes. These may include:

- creation of a unit or corner in the library with special collections on R\&I information (Chiware 2010:399);

- University Library Consortia advocating for this concept and even writing funding proposals to development partners seeking for the establishments of R\&I units in university libraries;

- periodical announcements by email to SMES on new R\&I information in the library;

- setting an SME day in the library where they can exhibit their entrepreneurial and innovative programmes;

- creating a page for SME on the library website with updated information on main R\&I events and links to R\&I information;

- depending on availability of funds, the library organising special workshops related to entrepreneurship and innovation;

- conducting information literacy training sessions for external researchers and SME entrepreneurs under the community engagement pillar (Chiware 2010:398);

- setting up reference and R\&I consultation services (Premkamolnetr 1999);

- offering voluntary or part-time employment to graduate students doing library and information science (LIS) courses to manage the library R\&I units and services for SMEs;

- adding this concept in the LIS curricular and preparing the upcoming LIS professionals for it in advance (Johnson et al. 2015:22).

\section{Recommendation}

Like the Libraries Transform campaign in North America alluded to earlier, it is now a matter of necessity that university libraries in Uganda and sub-Saharan Africa pick a leaf from this approach such that similar campaigns can be carried out this time focusing more on some of the suggestions above which can help university libraries support their community users with entrepreneurial and innovative business information.

\section{Conclusion}

Advancing positive changes in university libraries requires clear visions and effective infrastructures. A people-oriented university library should no longer strive for the market share, but instead should strive to also generate new brands, products and services for the market (Johnson et al. 2015:36). 
Because this study is largely based on literature analysis, there is a need to conduct a deeper empirical study on this concept not only in Uganda but also in the entire sub-Saharan African region and other developing parts of the world. Such empirical studies can go a long way to further future research and also quantify the major arguments in this article. Otherwise from the available corroborated literature and documentary evidence, if only university libraries in the African sub-Saharan region together with their stakeholders embrace this attitude, the contribution of libraries to SMES, the general business or entrepreneurial community and ultimately to sustainable development, will be undeniable.

\section{Acknowledgements \\ Competing interests}

The authors declare that they have no financial or personal relationship(s) that may have inappropriately influenced them in writing this article.

\section{Authors' contributions}

R.S.B. conceptualised the research idea, conducted the literature review and typed the work. S.M.M. reviewed the work, edited and analysed the content.

\section{References}

Aikaeli, J., 2007, 'Improving competitiveness for SMEs to harness available trade and investment opportunities: The case of Tanzania', The International Conference on SMEs and International Trade (Golden Tulip Hotel - Dar es Salaam, Tanzania), 27th-28th September 2007, Dar-es-Salam.

Ajidahun, C.O., 2006, 'Technical education and library services: A study of the federal science and technical colleges in Nigeria', Library Collections, Acquisitions \& Technical Services 30, 108-116. https://doi.org/10.1016/j.lcats.2006.07.007

Al-Qirim, N.A.Y., 2005, 'SMEs amidst global technological changes', in M. Khosrow-Pour, M. (ed.), Encyclopedia of Information Science and Technology, pp. 2519-2522.

Barclay, D.A., 2015, Turning a page: Downsizing the campus book collections, viewed 29 June 2016, from https://theconversation.com/turning-a-page-downsizing-thecampus-book-collections-45808

Beck, T., Demirguc-Kunt, A. \& Levine, R., 2005, 'SMEs, growth, and poverty: Crosscountry evidence', Journal of Economic Growth 10(3), 199-229, viewed 06 July 2016, from http://link.springer.com/article/10.1007/s10887-005-3533-5

Bowen, G.A., 2009, 'Document analysis as a qualitative research method', Qualitative Research Journal 9(2), 27-40. https://doi.org/10.3316/QRJ0902027

Brush, C., 1992, 'Marketplace information scanning activities of new manufacturing ventures', Journal of Small Business Management 30(4), 41-53.

Burkland, M., 1999, Library services in theory and context, 2nd edn., Berkeley Digital Library Sunsite, Berkeley, CA, viewed 12 July 2016, from http://digitalassets.lib. berkeley.edu/sunsite/Library $\% 20$ Services $\% 20$ in $\% 20$ Theory $\% 20$ and $\% 20$ Context, $\% 202$ nd $\% 20$ Edition.pdf

Chesbrough, H.W., 2006, 'Open innovation: A new paradigm for understanding industrial innovation', in H.W. Chesbrough, W. Vanhaverbeke \& J. West (eds.), Open innovation: Researching a new paradigm, pp. 1-27, Oxford University Press, Oxford.

Chiware, E.R.T., 2010, 'Positioning the technological university library in higher education and human resources development in Africa', Library Management 31(6), 391-403. https://doi.org/10.1108/01435121011066153

Dahlander, L. \& Gann, D.M., 2010, 'How open is innovation', Research Policy 3, 699-709. https://doi.org/10.1016/j.respol.2010.01.013

Drew, C., 2007, Encouraging use of entrepreneurship information resources: Faculty/ library collaboration, Worchester, viewed 08 July 2016, from https://www.wpi.edu/ Images/CMS/News/1063 ENCOURAGING_USE_OF_ENTREPRENEURSHIP INFO.pdf

Fink, A., 1998, Conducting research literature reviews: From the paper to the internet, Sage Publications, Thousand Oaks, California.

Fjose, S., Grünfeld, L.A. \& Green, C., 2010, SMEs and growth in Sub-Saharan Africa: Identifying SME roles and obstacles to SME growth, Oslo, viewed 09 July 2016 from https://www.norfund.no/getfile.php/133983/Bilder/Publications/SME\%2O and $\% 20$ growth $\% 20$ MENON\%20.pdf

Freeman, G.T., 2005, 'The library as place: Changes in learning patterns, collections, technology, and use', in Library as place: Rethinking roles, rethinking space, pp. $1-9$, Council of Library and Information Resources, Washington, DC, viewed 08 July 2016, from http://www.clir.org/pubs/reports/pub129/pub129.pdf/view
FSD Africa, FSD Uganda, Nathan Associates London Ltd \& TNS Africa, 2015, National small business survey of Uganda, Kampala, viewed 13 July 2016, from http:// www.fsdafrica.org/wp-content/uploads/2015/04/15-04-13-National-SmallwWw.fsdafrica.org/wp-content/uploads/
Business-Survey-Uganda.pdf?noredirect=1

Grand Valley State University, 2016, Get help from research consultants, University Library, viewed 29 June 2016, from http://www.gvsu.edu/library/get-help-fromresearch-consultants-15.htm

Hin, L.T.W.H. \& Subramaniam, R., 2005, 'Dot-coming SMEs in Singapore for the new economy', Encyclopedia of Information Science and Technology, 912-917. https:// doi.org/10.4018/978-1-59140-553-5.ch160

Ikoja-Odongo, J.R., 2002, 'A study of information needs and uses of the informal sector of Uganda: A PhD thesis in library and information science', PhD thesis, University of Zululand.

International Federation of Library and Information Associations \& Institutions, 2015, Cape Town declaration, Republic of South Africa, Cape Town, viewed 13 July 2016, from http://www.ifla.org/files/assets/wlic/2015/documents/cape-towndeclaration-of-ministers.pdf

International Federation of Library and Information Associations \& Institutions, 2016 Access and opportunity for all, IFLA, Hague, viewed 13 July 2016, from http:// www.ifla.org/files/assets/hq/topics/libraries-development/documents/accessand-opportunity-for-all.pdf

Jeffcoate, J., 2005, 'Adoption of e-Commerce in the value chain by SMEs', Encyclopedia of Information Science and Technology, 62-67. https://doi.org/10.4018/978-159140-553-5.ch013

Johnson, L., Adams Becker, S., Estrada, V. \& Freeman, A., 2015, NMC horizon report: 2015 library edition, Austin, TX, viewed 20 July 2016, from http://cdn.nmc.org/ media/2015-nmc-horizon-report-library-EN.pdf

Kanyengo, C.W., 2006, 'Managing digital information resources in Africa: Preserving the integrity of scholarship', Bridging the North-South Divide in Scholarly Communication on Africa. Threats and Opportunities in the Digital era, University of Zambia, Leiden, pp. 1-20.

Kinengyere, A.A., 2007, 'The effect of information literacy on the utilization of electronic information resources in selected academic and research institutions in Uganda', The Electronic Library 25(3), 328-341. https://doi.org/10.1108/02640 470710754832

Kulabako, F. \& Ojambo, B., 2016, 'SMEs to access friendly loans', New Vision, 19 April 2016, p. 34.

Lee, S., Park, G., Yoon, B. \& Park, J., 2010, 'Open innovation in SMEs - An intermediated network model', Research Policy 39, 290-300. https://doi.org/10.1016/j.respol. 2009.12.009

Libraries Transform, 2015a, Engagement, Web document, viewed 19 July 2016, from http://www.ilovelibraries.org/librariestransform/engagement

Libraries Transform, 2015b, The libraries transform campaign, Campaign, viewed 01 July 2016, from http://www.ilovelibraries.org/librariestransform/

Machacha, L., 2002, 'Impact of information technology on Small and Medium Enterprises (SMEs) in Botswana', in K. Kimppa (ed.), Proceedings of Expanding the
Horizons of African Business and Development, The International Academy of Horizons of African Business and Development, The International Academy of
African Business and Development International Conference, Port Elizabeth, African Business and Development Intern
South Africa, April 3-6, 2002, pp. 277-282.

Mansell, R., 2010, 'The information society and ICT policy: A critique of the mainstream vision and an alternative research framework', The Journal of Information Communication \& Ethics in Society 8(1), 22-41. https://doi.org/10.1108/ Communication \& E
14779961011024792

Miles, I., Kastrinos, N., Flanagan, K., Hertog, P.D., Bilderbeek, R., Bouman, M., et al., 1995, Knowledge-intensive business services: Users, carriers and sources of innovation, Manchester, viewed 12 July 2016 from https://www.escholar.manchester.ac.uk/api/ datastream? publicationPid=uk-ac-man-scw:75252\&datastreamld=FULL-TEXT.PDF

Ministry of Finance Planning and Economic Development, 2011, Development of a national Micro, Small and Medium Enterprises (MSMEs) policy and strategy, Republic of Uganda, Kampala, Uganda.

Mutula, S.M., 2005, Assessment of the e-readiness of small and medium sized enterprises in the ICT sector in Botswana, with special reference to information access, University of Johannesburg, viewed 19 July 2016, from http://ujdigispace. uj.ac.za/handle/10210/1854

Mutula, S.M. \& Van Brakel, P., 2007, 'ICT skills readiness for the emerging global digital economy among small businesses in developing countries Case study of Botswana', Library Hi Tech 25(2), 231-245. https://doi.org/10.1108/073788 30710754992

Nakibuule, R., 2015, Government pledges support to SMEs, Monitor Publications, Kampala, p. 26.

Neal, J.G. \& Mcclure, P.A., 2003, 'Organizing information resources for effective management', in P.A. McClure (ed.), Organizing and managing information resources on your campus, pp. 29-44, Jossey-Bass Inc., New York.

North Carolina State University Library, 2016, Makerspace, viewed 29 June 2016, from https://www.lib.ncsu.edu/services/makerspace

Perkmann, M. \& Walsh, K., 2007, 'University-industry relationships and open innovation: Towards a research agenda', International Journal of Management Reviews 9(4), 259-280. https://doi.org/10.1111/j.1468-2370.2007.00225.x

Peterson, C.A., 2005, 'Space design for life long learning: The Dr. Martin Luther King Jr. joint-use library', in K. Smith (ed.), Library as place: Rethinking roles, rethinking space, pp. 56-65, Council of Library and Information Resources, Washington, DC.

Ponelis, S.R., 2011, An exploratory study of business intelligence in knowledge-based growth small, medium and micro- enterprises in South Africa, University of Pretoria, viewed 18 July 2016, from http://repository.up.ac.za/dspace/handle/ 2263/28042 
Premkamolnetr, N., 1999, 'Collaboration between a technological university library and tenant firms in a technology park in Thailand: New challenges for librarianship in a developing count

Republic of Uganda, 2006, Universities and other tertiary institutions act, 2001, Uganda National Council of Higher Education, Uganda, viewed 12 July 2016, from http://www.unche.or.ug/wp-content/uploads/2014/11/Universities-and-OtherTertiary-Institutions-Act-2001.pdf

Rodrigues, R.J., 2001, 'Industry expectations of the new engineer', Science \& Technology Libraries 19(3-4), 178-188, viewed 13 July 2016, from http://www. tandfonline.com/doi/abs/10.1300/J122v19n03_12

Sarin, L., 2013, Entrepreneurship Librarian - Michigan State University, Web documen 2, viewed 08 July 2016, form http://mls.umd.edu/2013/05/entrepreneurshiplibrarian-michigan-state-university/

Schauder, D., 1987, 'Entrepreneurship and the academic library: Insights from organization theory', The 12th IATUI Bennial Conference, IATUI Conference, Helsinki, pp. 36-50, viewed 13 July 2016, from http://docs.lib.purdue.edu/iatul/ 1987/papers/10

Sekanjako, H., 2016, 'Government scraps roadside charges on taxi operators', The New Vision, 15 January 2016, p. 3.

Sridhar, M.S., 2007, 'Information management in digital environment: A librarian's perspectives', Desidoc Bulletin of Information Technology 27(4), 46-51. https:// doi.org/10.14429/djlit.27.4.186

Sseppuuya, D., 2016, 'Why I buy Uganda made tissue and no toothpicks', The New Vision, 21 January, 2016, p. 30.

Tambwe, M., 2016, 'Open university of Tanzania: Shining example of ICT usage in higher learning', The National Newspaper: Daily News, viewed 13 July 2016, from http://www.dailynews.co.tz/index.php/features/49598-open-university-oftanzania-shining-example-of-ict-usage-in-higher-learning

The Conversation, 2016, Has the library outlived its usefulness in the age of Internet? You'd be surprised, Web document, viewed 07 July 2016, from http:// theconversation.com/has-the-library-outlived-its-usefulness-in-the-age-ofinternet-youd-be-surprised-58198
The Republic of South Africa, 1996, National Small Business Amendment Act, South Africa, viewed 12 July 2016, from https://www.thedti.gov.za/business regulation/ acts/small_business amendment_act.pdf

The Republic of South Africa, 2003, National Small Business Amendment Act, 2003 Government Gazette, South Africa, viewed 12 July 2016, from http://www.saflii. org/za/legis/num_act/nsbaa2003331.pdf

Tibenderana, P., Ogao, P., Ikoja-Odongo, J.R. \& Wokadala, J., 2010, 'Measuring levels of end-users' acceptance and use of hybrid library services', International Journal of Education and Development using Information and Communication Technology (IJEDICT) 6(2), 33-54.

Uganda Bureau of Statistics, 2011, Uganda bureau of statistics report on the census of the business establishments 2010/2011, Kampala, viewed 8 July 2016, from http://www.ubos.org

Uganda National Council of Higher Education, 2016, Institutions, NCHE List, viewed 27 June 2016, from http://www.unche.or.ug/institutions

University of Pretoria, 2015, South Africa's first Library MakerSpace opens at the University of Pretoria, viewed 01 July 2017, from http://www.up.ac.za/en/news/ post 2062883-south-africas-first-library-makerspace-opens-at-the-university-ofpretoria-

Valentina, P., 2016, The poorest countries in the world, Web document, viewed 06 July 2016, from https://www.gfmag.com/global-data/economic-data/the-poorestcountries-in-the-world

Van De Vrande, V., De Jong, J.P.J., Vanhauerbeke, W. \& De Rochemont, M., 2009, 'Open innovation in SMEs: Trends, motives and management challenges', Technovation 29, 423-437. https://doi.org/10.1016/j.technovation.2008. 10.001

Zeng, S.X., Xie, X.M. \& Tam, C.M., 2010, 'Relationship between cooperation networks and innovation performance of SMEs', Technovation 30(2), 181-194. https://doi. org/10.1016/j.technovation.2009.08.003

Zou, S. \& Stan, S., 1998, 'The determinants of export performance: A review of the empirical literature between 1987 and 1997', International Marketing Review 15(5), 333-356, viewed 08 July 2016, from https://business.missouri.edu/zou/ Resume/zou-stan-imr98.pdf 